\title{
Dead Malls: Suburban Activism, Local Spaces, Global Logistics
}

\author{
VANESSA PARLETTE and DEBORAH COWEN
}

\begin{abstract}
An entire category of urban space, albeit hardly recognized as such, is disappearing across North America. As retail logistics globalizes and big-box power centres replace enclosed shopping malls from the postwar era, a distinct form of social infrastructure vanishes as well. 'Dead malls' are now a staple of North American (sub)urban landscapes, and have provoked local activism in many places. But despite popular concern for the demise of mall space, critical urban scholarship has largely sidelined the phenomenon. Much of the disjuncture between popular outcry and academic silence relates to conceptions of 'public' space, and specifically the gap between formal ownership and everyday spatial practice. Spatial practice often exceeds the conceptions of designers and managers, transforming malls into community space. This is particularly true in declining inner suburbs, where poor and racialized communities depend more heavily on malls for social reproduction as well as recreation and consumption. In this article we investigate the revolution in logistics that has provoked the phenomenon of 'dead malls' and the creative activism emerging that aims to protect mall space as 'community space'. Taking the case of the Morningside Mall in an old suburb of Toronto, we investigate the informal claims made on mall space through everyday spatial practice and the explicit claims for community space that arise when that space is threatened. We argue that many malls have effectively become community space, and activism to prevent its loss can be understood as a form of anti-globalization practice, even if it never employs that language.
\end{abstract}

\section{Introduction}

In June 2005, several hundred residents of Scarborough's Kingston-Galloway/Orton Park community (located at the extreme east end of Toronto's declining inner suburbs) took to the streets (see Figure 1). Seniors and youth, young families and singles, many of them newcomers, mostly people of colour and all residents of this heavily stigmatized neighbourhood, rallied to protest against the loss of 'community space'. This claim on urban space came from a neighbourhood known largely for gun crime, soaring levels of family poverty and a concentration of new immigrants from the far reaches of the globe. The demonstration was not centred on the privatization of a public park or the closure of a public recreation centre. This community, like so many others built in the postwar period, possesses few of the hallmark public spaces of a traditional urban realm. Built around the private family in private space, this suburban landscape has few truly public spaces that could ever be lost (Cowen, 2005). Rather, this struggle over a different kind of community space is one that now marks inner suburban communities across North America. This was a struggle over a dying mall.

A spectre is haunting devalorized postwar suburban landscapes across the United States and Canada - the spectre of 'dead malls'. Typically understood as one expired 


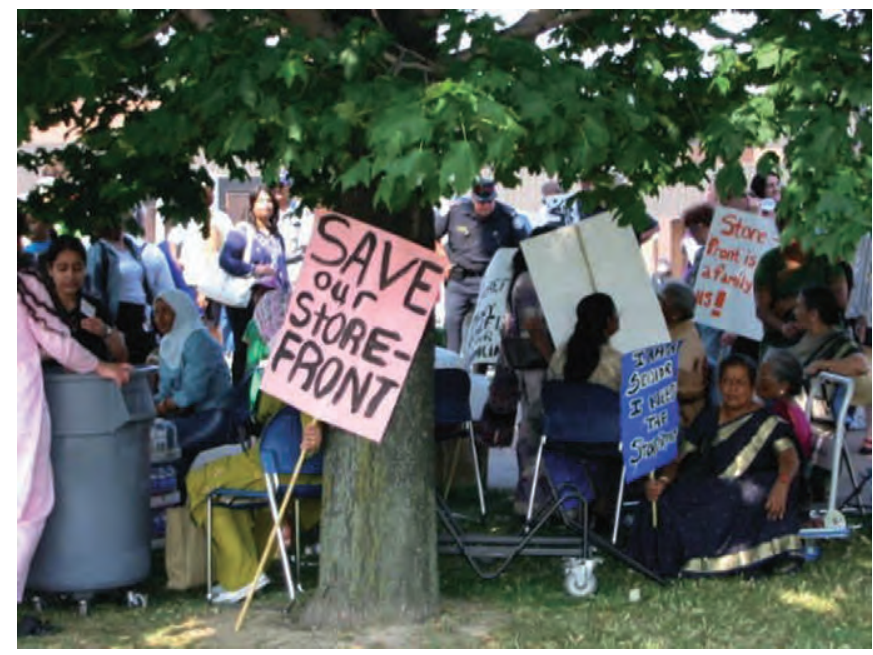

Figure 1 March to save the Storefront and Morningside Mall (source: East Scarborough Storefront, 2005)

corporate retail form simply substituted by another, the replacement of enclosed malls with big-box power centres has registered only a small body of literature within critical urban scholarship (for exceptions, see Wrigley and Lowe, 2002; Hernandez, 2003; Hernandez and Simmons, 2006) No doubt, 'private retail space' is an accurate description of the enclosed mall, and 'creative destruction' captures well the capitalist cycle of investment, disinvestment and re-investment that characterizes its current transformation. Nevertheless, the creative destruction of private retail space radically understates the significance and effect of this dramatic destruction and production of suburban space marked by the phenomenon of dead malls. Enclosed malls, as the residents of Southeast Scarborough in Toronto's eastern reaches were well aware, often became community space. While privately owned and managed, enclosed malls in inner suburbs are at times the only indoor spaces that offer some degree of public access. In spite of the powerful histories of racism, exclusion and surveillance that characterize these 'cathedrals of consumption', enclosed malls came to function as meeting spaces, de facto childcare centres, shelters, Tai Chi studios and drop-in centres (Pollock, 1992). Indeed, spatial practice always escapes and exceeds the conceptions of designers and managers ( $c f$. Lefebvre, 1991).

There is perhaps no better example of the private mall as community space than the now defunct and demolished Morningside Mall in this community in the east end of Toronto. A classic enclosed form, Morningside was home to a food court that served as an informal meeting place for a men's card club and a South Asian seniors' social group - uses that persisted long after the waning of the core retail function. Local residents used the halls of the mall as a walking route in the cold Canadian winter months and mothers would spend time with their children in strollers on benches, watching people go by. Social reproduction was a staple of mall life in addition to the consumption we know so much about. The mall was also home to organizations like the East Scarborough Storefront, a coalition of dozens of community groups visited by up to 5,000 residents each month, which provided everything from internet access to employment training to collective cooking groups, even a meditation group for Tamil seniors. But the local social story of Morningside Mall is also a global economic story of the globalization of logistics systems and corporate retail models. Indeed, it is none other than Walmart, the world's largest corporation, that is responsible for the demise of this private retail mall and community space, "When death-mart moved in and then 
subsequently moved out I never went back". That explains why the mall is closing' (interview with resident, 29 November 2007).

The closure of the Morningside Mall is just one drop in the bucket of a massive restructuring of (sub)urban space. An entire category of social space, hardly even recognized as such, is largely disappearing across North America. Not only has Walmart devised a deliberate and highly successful campaign of killing malls across North America (one that is imitated by big-box competitors that follow in its wake), but there has also been tremendous new growth in big-box investment across the region more generally by a number of corporate retailers (Hernandez and Simmons, 2006). The Morningside Mall thus offers a timely opportunity to explore two powerful and deeply entwined processes that are remaking urban social and economic space but which are rarely investigated as an ensemble: the decline of inner suburbs (Davis, 1997; Lucy and Phillips, 2000; Walks, 2001; Short et al., 2007); and the globalization of logistics and retailing (Bonacich, 2005). The story of dead malls is about the rescaling of logistics systems from the national to the global scale, and the unexpected social geographies and sites of political contestation that are made visible in the process. It is a story that 'socializes' the technocratic and seemingly faceless world of logistics' spatial calculation. With these questions in mind, this article investigates the life and death of the suburban mall, from the 'new main street' of the postwar era to the devalorized and expired form of recent years. We explore how the decline of the mall as a competitive retail form coincides with the growing use of the mall as de facto 'public' space. From the residents of Southeast Scarborough we learn important lessons. We see somewhat new and unexpected forms of contestation that we suggest may be understood as alternative sites of alter-globalization movements and, specifically, we see this claim on urban space as a challenge to the production of space purely for profit.

\section{Birth of the mall}

The outward migration of middle- and upper-class citydwellers, often described as 'white flight' and a 'hollowing out' of the inner city, defined North American urban development after the second world war. As the affluent fled the inner cities, industry and businesses also moved outwards to capitalize on available land and the expanding suburban market. ${ }^{1}$ The regional mall became the ubiquitous retail form across the North American suburban landscape, touted by developers as the harbingers of community and shopping convenience in the shifting tide of urban form and investment. This story has received extensive scholarly attention; postwar suburbanization precipitated the devaluation of the inner city, exacerbated by the subsequent loss of manufacturing and low-skilled jobs for the remaining city residents, many of whom were recent immigrants or African Americans. The result was a racialized process of segregation along class lines leading to social polarization and an intensified cycle of poverty in the inner city (Orum and Xianming, 2003; Parker, 2004; Hannigan, 2005). The growth of suburban malls seemed to encapsulate this racial and class segregation by replacing public squares with enclosed private environments that relied on security and surveillance to ensure the 'safety' of ideal consumers while excluding undesirable populations. These privatized 'palaces of mass consumption' were, like suburban homes, inaccessible by public transit and required a level of income and leisure unavailable to the largely racialized or ethnic working-class populations remaining in the city core (Cohen, 2000).

1 We recognize of course that suburbs of various types (including industrial, residential, elite and working-class developments on the urban fringe) had been in existence long before the second world war; it was during the postwar period, however, that the state took on a significant role in their promotion and regulation, and also when suburbs became stereotyped in Canada (Harris, 2004; Lewis, 2004). 
While developers at the time promoted the malls as new community centres akin to the public squares of the past, critics have rightfully emphasized that malls are carefully designed and managed on the basis of inclusion/exclusion to attract leisure-oriented consumers with disposable income, while excluding less likely purchasers through location, intimidation and surveillance. Managers worked to cultivate loyalty to their malls, and deliberately deployed the language and feeling of 'community'. Indeed, a discourse of 'community' has long been part of management strategies to forge affiliations and loyalty with target consumers, rather than encourage non-commercial functions such as public debates, social gathering, networking or (perhaps most unthinkable) protests. To the extent that these things have occurred in malls, they have typically been highly regulated and controlled, with the effect of creating 'community as a disciplinary strategy' (Staeheli and Mitchell, 2006: 982). Herein, the invocation of community is used simultaneously as a public relations strategy and as a form of control, which stifles the less consumer-friendly elements of public space (Lewis, 1990; Cohen, 2000; Staeheli and Mitchell, 2006).

Nevertheless, despite cynical managerial efforts to cultivate affect and identification as part of a project of accumulation, the attachments of people to mall space often came to exceed those designs. While a number of scholars have attempted to evaluate community claims within shopping centres, they have largely focused on developer-led efforts to construct loyal patronage (Lewis, 1990; Wrigley and Lowe, 2002; Staeheli and Mitchell, 2006). No doubt, these powerful efforts to place corporations and corporate space at the centre of affective economies demand critical scrutiny as they build privatized and exclusive social worlds anchored in consumer models of citizenship (Knights and Sturdy, 1997; Miller and Rose, 1997). However, is there a way we might acknowledge the force of corporate constructions of community in the space of the mall, while also recognizing the multitude of ways that people actually make use and make sense of mall spaces (Backes, 1997; Morris, 1999)?

Neglect of the ways people make use of space, or what Lefebvre terms 'spatial practice', contributes to realizing the fantasies of those powerful state and corporate actors who conceive space. Mall managers and designers aim to govern life through their plans, but never hold the power to control space that they ascribe to and desire for themselves. Spatial practice supersedes conceived space. People form attachments to malls and use mall space in ways that exceed and extend corporate plans for community. 'Spatial practice thus simultaneously defines: places - the relationship of local to global; the representation of that relationship; actions and signs; the trivialized spaces of everyday life and, in opposition to these last, spaces made by symbolic means as desirable or undesirable, benevolent or malevolent, sanctioned or forbidden to particular groups' (Lefebvre, 1991: 288). Indeed, malls are increasingly taking on social functions, such as recreation in the form of mall walking (Duncan et al., 1995; Anderson et al., 1998), youth and social programming, libraries and other non-commercial services (Manzo, 2002). While there is warrant to argue that permitting these venues is compatible with a consumer strategy to create a 'manufactured illusion' of community (Lewis, 1990: 122), events like the demonstration for community space at Morningside suggest that active claims on space and connections to place can nevertheless proliferate.

\section{Declining suburbs}

A distinctive shift in the class and ethno-racial composition of the postwar suburbs marks the remaking of urban space that provokes struggles over mall space. In many North American cities, the last two decades have witnessed not only the return of investment priorities to the revitalization of central cities, but also a rise in the suburbanization of poverty. This 'hollowing out' of the suburbs mirrors that of the inner city decades earlier. Gentrification works in tandem with the racialized suburbanization of poverty. The 


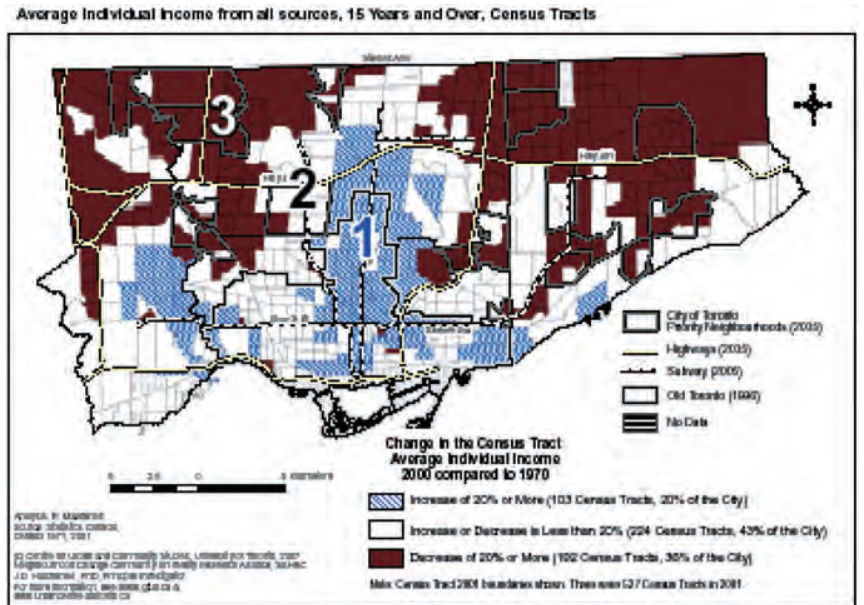

Figure 2 Change in average individual income, City of Toronto, 1970 to 2000 (source: Hulchanski, 2007)

displacement of inner-city residents through gentrification has led many to relocate to the suburbs, which are also the main sites of new immigrant settlement in many cities. Affluent residents are seen to flee while many suburban malls are losing some of their prime retailers. Coinciding with the loss of manufacturers, the rise of unemployment and spill-over effects from the city, suburbs are experiencing a growth of crime and decay in addition to the original suburban problems emergent from their very design (such as sprawl and lack of communal space) (Hannigan, 1998; Lucy and Phillips, 2000; Smith et al., 2001; Orum and Xianmeng, 2003; Short et al., 2007). This spatial process is an uneven one, resulting in a dual system of 'haves' (rich suburbs) and 'have nots' (poor suburbs) (Orum and Xianmeng, 2003: 127), corresponding to the global trend toward polarization within and across cities and nations. This trend is abundantly clear in the Toronto region where the inner suburbs of Scarborough, East York, York, North York and Etobicoke (all amalgamated into the City of Toronto in 1998) are home to increasing numbers of recently arrived immigrants, racialized groups and precarious workers. At the same time the areas face challenges of declining social and material infrastructure, selective social policy and record levels of poverty (see Figures 2 and 3). Meanwhile, this process of decline is occurring while the exurban growth of new suburbs beyond the postwar boroughs continues to see high levels of investment and resident incomes (Walks, 2001; United Way of Greater Toronto, 2002; Cowen, 2005).

The suburban landscapes that developed during the postwar period have come to be seen as 'places of sacrifice' (Hannigan, 2005), as privatism, auto-dependency, lack of communal gathering space and impoverished civic engagement has elicited widespread critique and hostility toward these regions (Davis, 1990; Kunstler, 1993; Parker, 2004). Revitalization of inner-city landscapes coincides with disinvestment and neglect of the 'expired' suburban form. Overinvestment in the suburban landscape through the 1960s and 1970s oversaturated the potential for expanding markets, both in terms of housing subdivisions, which were even beginning to seem crowded in the once seemingly endless space, as well as retail markets. "After twenty years of constant expansion, suburban retailing had become oversaturated leading to consumer fatigue .. . "Shop "til you drop" has progressed to "malled to death" ' (Hannigan, 1998: 62). At the same time, growing consumer frustration with standardized goods and demand for more specialized cultural products challenged the mass-production model that had bolstered the historic dominance of the regional mall (Harvey, 1990; Jones and Doucet, 2001; Wrigley and Lowe, 2002). While downtown regions see a renaissance in chic value-added retail 


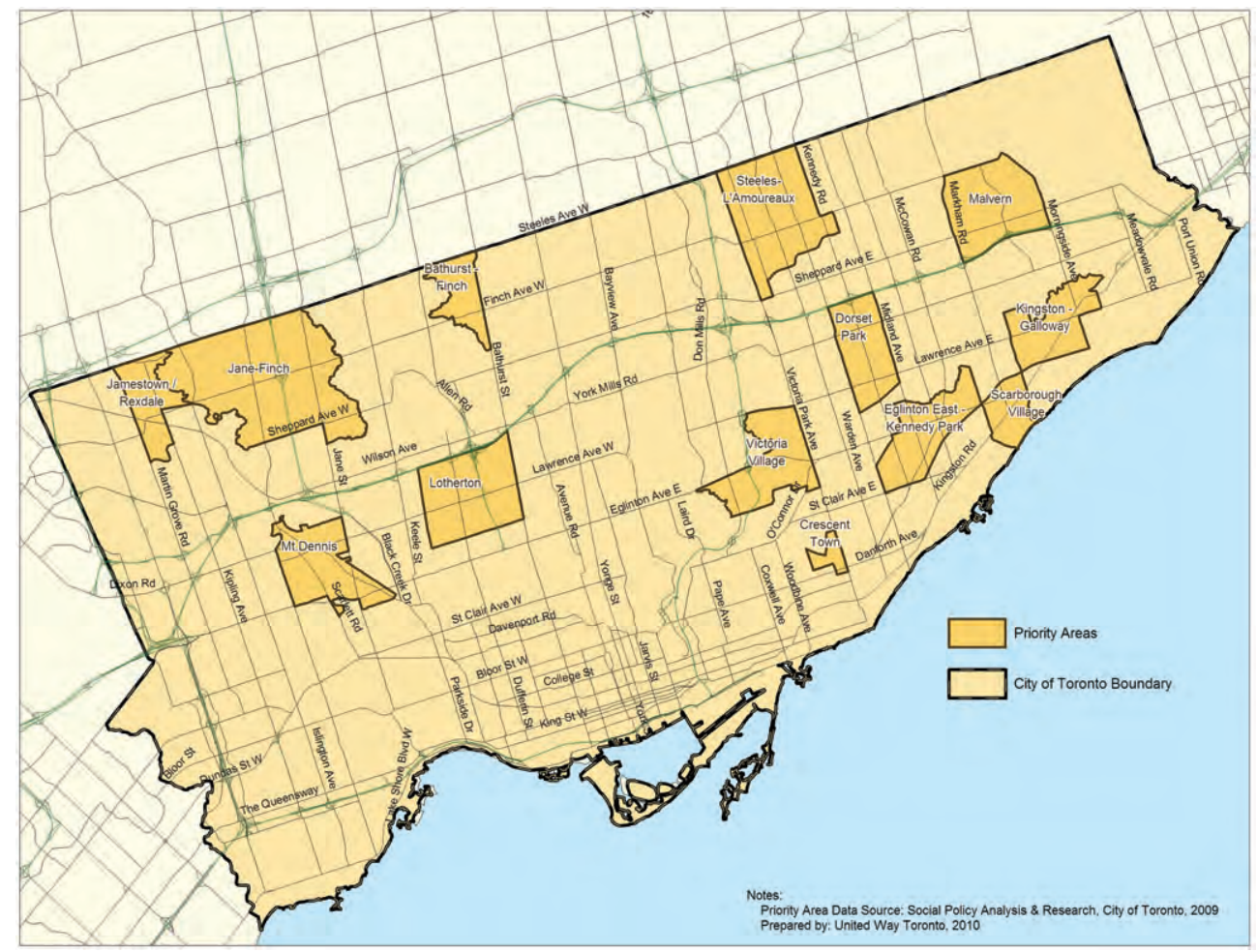

Figure 3 Map of Toronto's 13 Priority Neighbourhoods, designated for targeted investment due to high levels of poverty and lack of social services and infrastructure. Kingston-Galloway/Orton Park is in the southeast corner (source: City of Toronto, 2009)

supported by an influx of an upwardly mobile clientele, postwar suburbs absorb the fallout of unwanted uses and users of the core city space. Nowhere is this trend more evident than in a municipal report entitled the 'Future of Downtown Toronto' (City of Toronto, 2000). Downtown Toronto employment has grown more quickly than that of the rest of the city as well as the country as a whole, particularly through high-level office growth in finance, insurance and real estate (FIRE) as well as business services (ibid.: 10-11). The perceived need to attract such industries is driven by a fear that if they do not locate in Toronto they might leave Canada altogether, and so the report mandates that public investment and development support these priorities that are geared towards trapping footloose capital and luring ideal people (consumers and skilled professionals) into the downtown.

However, in order to make room for the coveted transnational boom, the downtown core needs to 'make space' (Lefebvre, 1991). The report states: 'In this regard the movement of lower value added functions out of the downtown to other parts of the region could strengthen the downtown by releasing space for higher value added activities in the downtown and the region' (City of Toronto, 2000: 41). On the other hand, low-wage and precarious service-sector and retail jobs and workers (United Way of Greater Toronto, 2002), are displaced to the former suburbs while traditional manufacturing industries relocate further from the core to the exurbs or abroad. This displacement is indicated in a Scarborough Centre report, which states a need to attract more businesses and jobs to the area which 'could include traditional industrial jobs, along with offices, retailing and services that are looking for inexpensive space and do 
not need prominent locations' (City of Toronto, 2001: paragraph 3, emphasis added). The multi-scaled impact of retail logistics is a not so invisible hand in this process. As the professionalization of the downtown core assumes a dominant role in the command and control function of the supply-chain management process, manufacturers are simultaneously pressured to cut costs by exploiting lax labour standards further away from core cities and countries. The cheaply made products then come back to fuel a consumption-oriented economy propped up by low-wage service and retail workers in marginalized spaces of the 'north' (Prytherch, 2007).

\section{Retail revolution and revolutionizing retail}

Sam Walton and Walmart have transformed retailing the way Henry Ford revolutionized transportation.

(Ortega, 1998: xv)

The 'retail revolution', as described by authors such as Bonacich (2005) and Wrigley and Lowe (2002), would not have been possible without a 'logistics revolution'. The revolution in logistics entailed a radical restructuring and globalization of 'distribution in production' or 'the movement and storage of goods' (Bonacich, 2005: 359). This comparison between retail logistics and the social transformations ushered in through Fordism points to the multi-faceted impact that seemingly abstract economic processes have on locally experienced daily life and urban space. These systems of production management are simultaneously entangled with the spread and perpetuation of private transportation and the political, social and industrial contexts in which they have emerged (and which they have influenced). Just as Fordism became a label used to describe the postwar social order as one based on mass production, the revolutionized approach to consolidated supply-chain management, enabled by sophisticated information technology, transportation advances and communication networking, has facilitated the dominance of corporate retail capital over manufacturers. The characterization of the new economic order as post-Fordism signals that this transformation has not simply stopped at a revolution of retail markets but has gone on to transform, or revolutionize, the way spaces are manipulated, utilized and inhabited (Harvey, 1990; Bonacich, 2005).

It is this type of technological innovation that has induced the 'big-box format'. Companies such as Walmart and Home Depot have developed and exploited advanced logistical systems, which propelled flexible accumulation into the dominant form of production and facilitated the ascendance of retailer power (Amin, 1994; Aoyama and Ratick, 2007). This model challenges the pre-existing supply-demand system of mass manufacture, where retailers would buy and attempt to sell suppliers' products as best possible, while assuming the risk of stock-outs for popular items or over-accumulation through lost sales. The shift to a 'pull' system depends on information technology to create a demand-driven model. Via electronic point of sale technology and data management, customer purchase information is instantaneously transported backwards through the supply chain to manufacturers who are then responsible for distributing, literally 'on demand'. This model facilitates shorter and more customized production cycles and is intended to reduce the risks endemic to capitalism by eliminating the imbalance between supply and demand (Wrigley and Lowe, 2002; Vias, 2004; Bonacich, 2005). However, as with most capitalist 'fixes', supply-chain management does not eradicate risk, but simply shifts it to other points on the supply chain, to manufacturers as well as other retailers and (less often considered) to local communities.

Big-box stores are generally characterized by immense warehouse-style stores that are atypical for the type of products sold. The size of these stores varies from a square footage of 20,000 for specialty items to 120,000 for general merchandise (Maryland 
Department of Planning, 2001). The early growth of 'category killers' which encompasses stores such as Toys R' Us, Office Depot, Lowes and Home Depot, signalled an ability to undercut and 'kill' competitors in a specific consumer category by exploiting the big-box format, a model pioneered and typified by Walmart (Spector, 2005). These stores have been immensely successful at streamlining logistics by buying direct from manufacturers, thereby cutting distribution costs (and distributor jobs, one might add) and eliminating onsite storage - typically less than $12 \%$ of a big-box store is devoted to non-sales (Burt and Sparks, 2001). The massive volume purchasing that makes direct buying possible also puts tremendous pressure on manufacturers to bend to retailers' demands for low pricing and other concessions, or else risk losing an incomparably large customer, whose business can make or break a company. Walmart in fact strictly demands everything from technology adoption, changes in packaging, a vow of silence (suppliers cannot discuss their relationship with the company), and remarkably a 5\% price drop per year if a company wants to continue selling to Walmart. Indeed, the sheer size of big-box companies means they have the power to undertake their own distribution and take control of the entire supply chain, with or without external suppliers. 'If they don't like your prices, they'll go vertical and do it themselves - or they'll find someone that will meet their terms' (Fishman, 2006: 97).

The ability of large-scale retailers to control the entire supply chain epitomizes the power shift of retailers over manufacturers that is characteristic of the retail revolution, or a shift from a mass-production to a consumption economy. The constant pressure to cut costs accelerates the loss of manufacturing jobs in high-wage countries, intensifying enormous labour and environmental exploitation in the developing world and creating a low-wage service sector in the de-industrialized north. This is clearly delineated by the 3.1 million lost manufacturing jobs in the US between 1997 and 2004 coupled with an increase of 480,000 Walmart jobs, ${ }^{2}$ which now make up $70 \%$ of American retail employment (Ortega, 1998; Dawson, 2000; Dawson et al., 2006; Fishman, 2006: 105). The three largest importers to the United States are now retailers, with Walmart at the top, importing more than six times the amount of tonnage as General Electric - the first manufacturer on the list. Half a decade ago General Motors lost its seat at the top of the Fortune 500 chart, when it was surpassed by Walmart (Bonacich, 2005: 361). By the end of 2008 Walmart had been deemed 'recession-proof', as the company managed to report 9.8\% earnings growth in the face of a worldwide economic downturn (Bustillo and Zimmerman, 2008), at the same time that General Motors (among many other corporations) pleaded for government bailouts to avoid bankruptcy (Mckenna and Wingrove, 2008).

While the big-box format is facilitating 'the retail revolution', it is just as surely revolutionizing retail. The ability to cut middleman costs and demand specialized pricing means that big-box stores can sell merchandise for less than traditional retailers can buy at cost (Ortega, 1998: xv). This has in turn transformed the nature of retail competition from quality and service to volume and price. The inability of smaller merchants to compete with the big-box formula has been well documented, especially in small towns, wherein the closer a retailer is to a big-box store, the greater the business loss. Communities worldwide have long struggled with the impacts of big-box entry to neighbouring regions, where towns within a 20-mile radius will typically experience severe drain, if not business closures (Brennan and Kundsten, 2000; Davidson and Rummel, 2000; Peterson and McGee, 2000; Burt and Sparks, 2001; Javorcik et al., 2008). Large cities such as Toronto have seen similar effects, such as the decimation of traditional hardware stores due to the cannibalizing expansion strategies of Home Depot since entry to the Canadian market in 1992 (as just one example; see Hernandez, 2003). However, it is not only smaller retailers but also traditional department stores that still follow a decentralized buying model; having been slow to adapt to logistics innovations

2 This number refers to jobs at Walmart alone, and therefore fails to capture the number of similar jobs with other discount retailers. 
they have seen steady decline. Within Canada specifically, Walmart had $24 \%$ of the department-store retail market only two years after entry, and sales were up 378\% after less than a decade in the Greater Toronto Area (Jones and Doucet, 2001; Wood, 2002; Wrigley and Lowe, 2002; Turner, 2003). But this story does not end at the revolution of retail or the globalization of big boxes, these global political-economic transformations have ramifications that infuse the social body — permeating daily life and spatial practices in both obvious and unexpected ways.

\section{Death of the mall}

Suburban malls have to a large extent been cast as a redundant urban form, similar to the postwar suburbs in general. Big-box corporations clearly encapsulate an enormous shift in retail power and dominance; less dwelled upon, however, is how the transformation of the retail market is manifest in the urban landscape. The rapid replacement of regional suburban malls with big-box developments represents a local production of space in this multi-scalar logistics network. The shifting (and some may argue diminishing) role of nation states and development of supranational trade bodies such as the International Monetary Fund and the World Bank along with the North American Free Trade Agreement in particular, have played a major role in opening up the Canadian economy to American big-box companies (Dawson, 2000; Wrigley and Lowe, 2002; Hernandez, 2003; see also Javorcik et al., 2008 for impact in Mexico). At the same time, the devolution of fiscal responsibility onto municipalities, most poignantly obvious in Toronto through the offloading of social services in 1998, has meant that cities have been forced to compete for the imagined benefits from development and growth. This has resulted in less restrictive zoning policies, such as the removal of height and density limits as well as a slew of tax incentives and subsidies (Jones and Doucet, 2001). These retail behemoths have so much sway that the question for city officials often becomes not just whether to let them in but whether to lure and support them (Maryland Department of Planning, 2001).

How these wider policies materialize in the expansion of big-box stores in Canada, and the GTA in particular, has been starkly spatial. ${ }^{3}$ Walmart's strategy to cluster stores around distribution centres and saturate the market drastically cuts transportation costs, while gaining an edge on location compared to the somewhat random development of malls (O'Graff, 1998; Turner, 2003). A key entry strategy is to overtake existing businesses, such as Walmart's takeover of 150 Woolco stores in 1994.

It has since then been rapidly replacing malls, whereas previously malls were 'protected from competition by land use controls - either from competition from other malls, or from free standing retail outlets' (Hernandez and Simmons, 2006: 477). Key to this shift is the big-box 'de-malling' strategy, which essentially means they buy into an existing site and close off the mall entrance, typically leaving the internal corridor to die. Once established, the box store will often depart to a stand-alone site (Maryland Department of Planning, 2001; Hernandez and Simmons, 2006). In fact, from 1994 to 2001 the square footage of box stores in the GTA expanded by more than $125 \%$, while investment in mall development came to a standstill (White and Gray, 1996; Hernandez, 2003: 93$)^{4}$

3 GTA refers to the Greater Toronto Area, a large metropolitan area including and surrounding Toronto. The population of over 5 million is comprised from 25 municipalities and four regions: Durham, Halton, Peel and York (www.greatertoronto.org).

4 Although our case focuses on Toronto, this is not by any means strictly a GTA phenomenon. There are a number of blogs that have sprouted in recent years to document the decline of regional malls, such as labelscar.com and deadmalls.com. Big-box stores are implicated in the death of innumerable malls on these sites, many of which evidence community functions. 
That big-box stores are most concentrated in the suburbs is indicative of both a hostility toward the potential 'suburbanization of downtown' (Hammett and Hammett, 2007) as well as a wider political-economic shift in urban governance towards the enhancement of downtown spaces as part of a wider gentrification and global investment strategy (Hackworth, 2001; Smith, 2002). Although big-box developments have encroached somewhat upon downtown space they are much more common to suburban zoning; through a survey of big-box locations across Canada, Hernandez and Simmons (2006: 479) have indicated that only 5.6\% of these are in downtown regions. Big-box stores that have forced their way into the core are typically less pervasive, often tucked into industrial zones, while established neighbourhoods are protected through municipal policy (Jones and Doucet, 2001; City of Toronto, 2002). Suburban spaces on the other hand offer an established road network and dispersed urban form that can accommodate transportation routes and large stores (Keil and Young, 2008), while at the same time offering degraded spaces that are no longer seen to be fulfilling their proper retail function (McKay, 2007). The replacement of community malls is a highly uneven and unequal process, which is poignantly demarcated by class and race distinctions. Certainly not all malls that are forced to compete with big-box stores are closed or replaced; more affluent neighbourhoods may see a trend toward 'mixed-use' enhancedvalue retail centres that mimic traditional downtowns; others may be revitalized into theme, specialty or luxury malls (Wrigley and Lowe, 2002). Nevertheless, the death of enclosed malls in struggling postwar suburban communities remains a pervasive and pressing phenomenon.

The aesthetics of big-box development, the exploitation of labour, the impact on businesses, and the perpetuation of sprawl and auto dependency that are perpetrated through this change in retailing and urban form have wrought sharp and warranted critique (Ortega, 1998; Lorch, 2005; Fishman, 2006). However, the extension of big-box ramifications demands that we also question the implications for community space that emerge through the loss of regional malls. Asking such a question is complicated by the difficulty involved in recognizing community space within private places as well as the commercialized and exclusive function for which malls have been designed. The failure to take community space seriously poses the danger of idealizing a nostalgic yearning for a 'pure' public space that may not actually exist anywhere, while failing to recognize and support those already in existence, however imperfect and contested (Brill, 2001). The death of the mall will be overlooked if we fail to appreciate creative spatial practice in private mall space, or are unable to accept this as a massive loss of community space.

\section{Mourning Morningside}

Morningside Mall in Southeast Scarborough (which generated the protest mentioned at the beginning of this article) was built in the late 1970s and has long been recognized as the hub of community life in what is one of Toronto's most impoverished neighbourhoods (United Way of Greater Toronto, 2002). Located at the apex of Kingston Road, Morningside and Lawrence Avenues, this enclosed mall sat in the middle of a major arterial running through east Toronto. The building itself was three storeys high and measured just over 26,000 square metres (McKay, 2007), large enough to support the retail needs of the community until well into the 1990s, but small enough to support a community among neighbours. Originally anchored by a Woolco department store and a Dominion grocery chain, the mall was otherwise tenanted by a mix of independent mom-and-pop stores and larger chains, as well as medical offices and a public library. Throughout the mall's first two decades it supported both a vibrant retail and community life; Morningside Mall has historically drawn local residents to gather both formally (for community programs and services) and socially, such as to gather and play cards or practice Tai Chi in the food court or socialize with neighbours (Dickson, 2007; West-hill, n.d.; see Figure 4). 


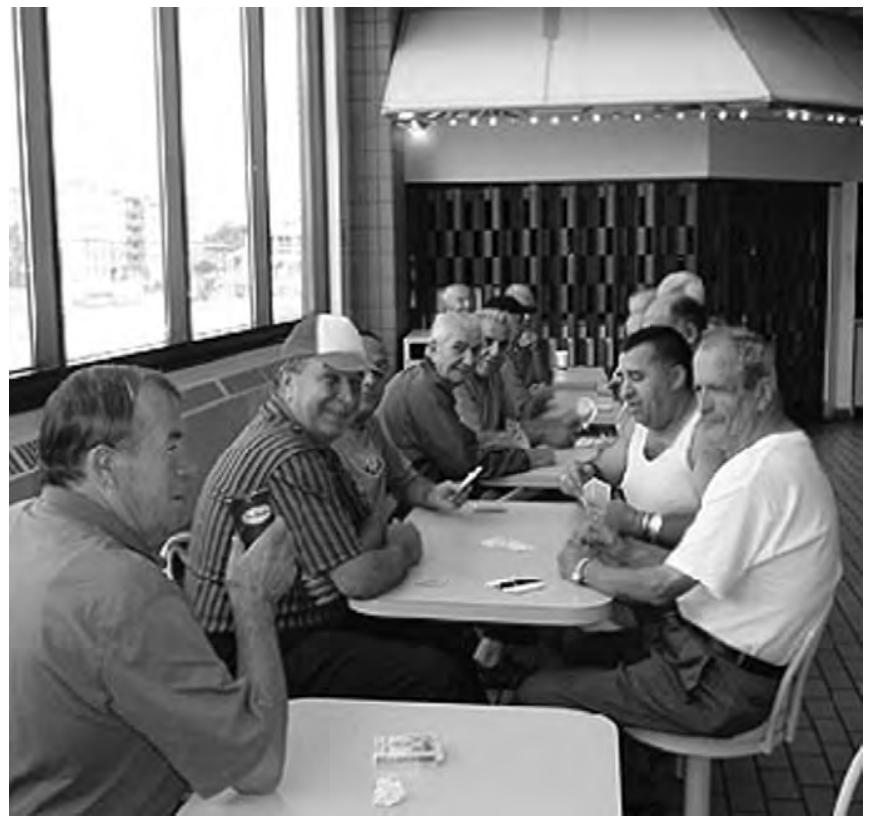

Figure 4 Morningside Mall food court (source: Author's photo, 2005)

In the late 1990s, the neighbourhood surrounding the mall began to change. During this period, there was a surge in construction of public housing and other high-rise apartment buildings, providing accommodation for many recent immigrants and fixedincome seniors. The significance of the mall as a gathering space increased along with pedestrian traffic, as many of the tower tenants did not have vehicles. Need for services in the area similarly increased as a number of motels along Kingston Road were converted into shelters housing over 1,000 refugee and homeless families (Philp, 1996).

Also in the late 1990s, Walmart entered the mall through the purchase of Woolco. At this time mall life was still active, but as Walmart de-malled their entrance to the internal corridor, smaller stores slowly began to die. Vacancies increased and made it possible for more community groups to enter. In 2001, the East Scarborough Storefront (ESS) made a home in the mall, inhabiting the former space of the public library that had moved down from the third to the second floor. ESS is a coalition of more than 40 community groups and organizations providing free services, programs and referrals in the fields of health, education, employment, settlement, parenting, legal services, community information and volunteerism while offering community gathering space and access to computers, fax and phone. ESS serves up to 5,000 local residents per month with their general services, and functions as a vital space where people can meet, youth can do homework, and links are made between various community agencies and support structures (ESS, n.d.). Since inception in 2001, ESS has held regular 'Community Speaks' rooted in a community organizing and civic engagement mandate. The 'Speaks' are forums which bring together diverse residents of Scarborough to question, discuss and strategize in large and small groups, focusing on issues related to community planning, transit, food security, health, safety and wellbeing of the community. Each of the 'Speaks' builds on the issues, questions and actions that have evolved since the previous one, with the goal of ensuring that ESS activities continue to reflect and support local priorities (ESS, 2004; 2005).

In 2003 Walmart departed the Morningside Mall location and set up at a big-box power centre down the road at the edge of a major freeway (highway 401). Although 
Walmart has been successful in its new location, its previous customer base residing around Morningside Mall has had difficulty reaching the store due to lack of bus service (ESS, 2004). The loss of the Walmart anchor was perceived by many to be the beginning of the end. After the Dominion grocery store left in 2004, leaving Morningside anchorless, many of the internal businesses suffered massive customer loss and the mall was designated a greyfield - a description that typically refers to a failed retail site. A greyfield classification is applied to malls with less than CDN \$150 in sales per square foot and a vacancy rate of at least 10-15\% (Bodzin, 2003). During this time of retail devastation, the community and public functions continued to thrive, with many local residents identifying the mall as the heart of the community and ESS as the communication hub (ESS, 2004; 2005; Gray, 2005). However, despite the clear communal value that ESS and the mall itself has for local residents, as conducive to the Toronto Official Plan's articulation of intensive redevelopment to increase density along Kingston Road (City of Toronto, 2003), the planned destruction of the mall to be remade into big-box stores was announced by the owners, Palmer Holdings and Sunlife Financial, in 2004 (McKay, 2007: 16; see Figures 5 and 6).

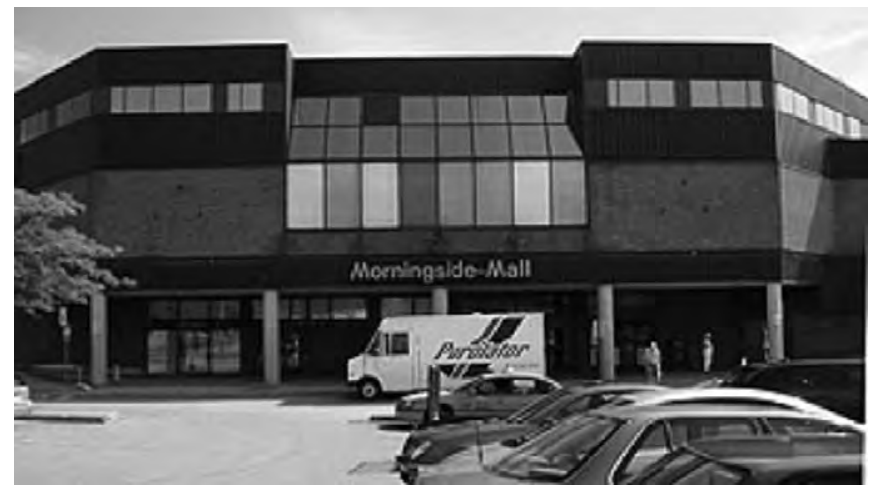

Figure 5 Morningside Mall prior to demolition (source: Author's photo, 2005)
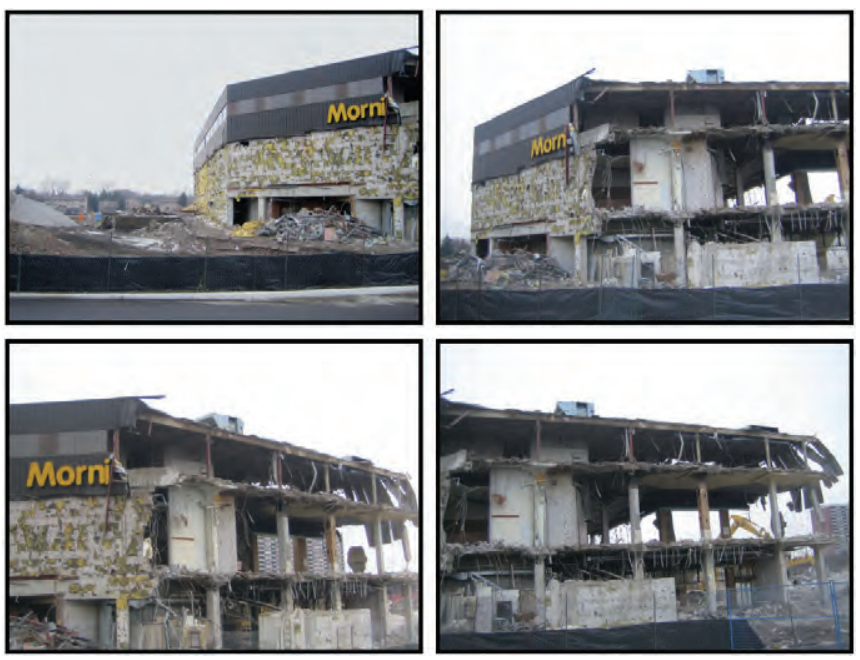

Figure 6 Morningside Mall demolition (source: courtesy of East Scarborough Storefront) 
The closure of the mall struck a drastic blow to the surrounding community and the announcement generated local outrage over the loss of one of the only public spaces in the area. Many of the (past) users of the Storefront space and Morningside Mall cannot drive and depended on the one-stop conglomeration of essential services and communal space that the mall offered; replacement with box stores does not fulfil those needs (Lori Metcalfe, community worker and resident, in Gray, 2005). At the Community Speaks of 2004 and 2005, public residents spoke of the mall as central to the community, while many expressed anger that the retail plaza was intended to serve the needs of middleclass consumers driving in from other neighbourhoods.

Local opposition intensified and spawned a large public march in 2005 to protest against the loss of community space and dislocation of the East Scarborough Storefront (ESS, 2004; 2005). The erosion of already limited public space and displacement of social infrastructure, at the expense of the city's neediest residents, insidiously reflects the challenges facing Scarborough and the former suburbs in general. Moreover, Morningside is a site where the community space of a mall was transformed into public protest and mobilization. However, this does not eliminate the tensions between public and private space. Despite intense local opposition from users of the space, demolition plans were carried forth unhindered and also facilitated by the city through the use of 'creative land use permissions'. These included the removal of height and density limits as well as a holding provision to allow future conversion to mixed-use development (McKay, 2007: 17). While local city councilor Ron Moeser acknowledges that the community 'wanted to see Morningside replaced by an indoor mall', he suggests that 'there's "a certain acceptance now" that isn't going to happen' (Adler, 2007). At the same time, before the final demolition of the mall in November 2007, the last standing users expressed knowledge that the new development underway was not for them: 'Nobody's going to think about us, they want to make money' (ibid.). The loss of the mall has brought a great lament to the community that has manifested itself on blogs ${ }^{5}$ and in 2006 prompted a coalition of a number of local groups that collaboratively planned a forum on 'Public Space in the Suburbs' (Planning Action, 2006) and have continued to organize events in support of resident participation in local planning issues (Amazing Place, 2007). ${ }^{6}$

It would seem that the logistics efficiency of big-box streamlining (if the mere $12 \%$ of non-sales space is any indication) has left no room for community space. The transformation of the Morningside region clearly devalues the pre-existing uses and users of the space as 'underdeveloped' (City of Toronto, 2003: 9), in favour of 'reurbanization' that serves the needs of capital accumulation. While the tax base and consumption revenue that the new box stores bring in may help fill government coffers, ${ }^{7}$ the existing locally accessible community space (which is already so scarce in the geographically dispersed Scarborough region) will be lost. The enactment of the official vision for the area obliterates the public-use value of the mall in conversion to the exchange value of the shopping complex that will take its place, exemplifying an explicit orientation towards consumers who shop rather than citizens who debate and socialize (Harvey, 1990). Ironically, despite the emphasis on reducing sprawl, 'smart growth' and aesthetic planning, the box stores that will be remaking the Morningside Mall site are an icon of urban sprawl and car dependency (Lorch, 2005). Clearly, the designated 'redevelopment'

5 For example: http://westhillnews.blogspot.com - 'Farewell Old Friend'. Similar public opposition occurred during the demolition of Don Mills Mall in North York. See 'Don Mills Centre redevelopment stirs conflict' (Hume, 2006).

6 While these events are significant to activism in the community after the loss of the mall, focus on these processes is beyond the scope of this article.

7 The amount of tax revenue may not be that significant, depending on the level of incentives such as waiving development fees or tax breaks that are endorsed by the Toronto Official Plan. 
for the site works in the interest of 'best use' (albeit debatable) for capital rather than people.

\section{Dead malls, collective life}

When we are open to the myriad ways people make use of space in their everyday practice, we see a wealth of relations and contestations that would otherwise remain concealed by official categories of public space and private property. 'Public' and 'private' are categories that have been subject to extensive critique and revision by critical scholars; bell hooks (1990: 42-3), for example, challenged white feminist critiques of the home when she argued that it is not simply a private space of domestic confinement, insisting that, for African Americans, the home often functions as a site of resistance in a hostile dominant white culture. Chauncey (1996: 258) describes how for homosexual men living in New York City in the 1920s and 1930s 'privacy could only be had in public'. He explains the complex tactics that these men performed in order to create spaces for intimate encounters, and the alternative mappings of urban space that this created. Chauncey further argues that it was not just gay men, but working-class youth too who contested bourgeois norms of sexuality and public behaviour (ibid.; see also Valentine, 1993). Donna Haraway (1991: 170) also points to the limitations of the public-private divide as a useful means by which to examine social relations in the contemporary world, suggesting that the divide may obscure more than it reveals. Haraway proceeds to look at sites that have typically been associated with one side of the binary, such as the home, state and workplace, and reveals how impossibly entangled they have become given political, technological, economic, social and cultural change. Finally, postcolonial scholars remind us of the violence of 'the public', how colonizing states' claims to 'the public' were often the face of dispossession.

These different readings of the public-private divide suggest that we need to pay close attention to how spaces are used, and not just how they are officially classified. Dead malls pose a similar challenge. They demand that we keep a focus on spatial practice that is often obliterated by the formal distinctions and jurisdictions associated with conceived space. Typical conceptions of malls as private space make it difficult to make sense of the outpouring of community response to the closing of retail malls, and perhaps impossible to see this struggle as connected to globalized production and distribution systems.

Morningside Mall is a prime illustration of the conflict inherent in privatized public spaces - that despite collective voice and action the 'public' still had no impact on the fate of 'their' space. However, Morningside reveals the need to consider spatial practice beyond our preconceived notions of what goes on in spaces designed for private use. This neglected area of study signals the potential for a vast range of exploratory ethnographic revisionings of public space and spatial practices in surprising places. The Morningside residents join in the cacophony of voices that struggle for spatial justice in the placeobliterating globalization of capital expansion. Along with others contesting the loss of public space in dying malls (Hume, 2006), or the replacement of public functions with privatized consumer leisure (Mitchell, 1995; Lowes, 2002), these protests imprint an unanticipated and indelible face on globalization that demands a place for the social, the political and the commons. To recognize that a space, despite a commercial origin, can function as a community hub may facilitate more adaptive redevelopments that support existing and flourishing public functions rather than the attempted resurrection of failing economic ones.

Vanessa Parlette (parlettev@geog.utoronto.ca) and Deborah Cowen

(deb.cowen@utoronto.ca), Department of Geography, University of Toronto, Sidney Smith Hall, 100 St. George Street, Toronto, Ontario M5S 3G3, Canada. 


\section{References}

Adler, M. (2007) Morningside crossing takes shape in West Hill: some favour retail development, others lament loss of covered mall. The Scarborough Mirror 10 August [WWW document]. URL http://www. simcoe.com/article/46728 (accessed 21 October 2008).

Amazing Place (2007) A community 'hunt' for local history in South East Scarborough. Independent DVD.

Amin, A. (1994) Post-Fordism: models, fantasies and phantoms of transition. In A. Amin (ed.), Post-Fordism: a reader, Blackwell Publishers, Oxford.

Anderson, R., S. Franckowiak, J. Snyder, S. Bartlett and K. Fontaine (1998) Can inexpensive signs encourage the use of stairs? Results from a community intervention. Annals of Internal Medicine 129.5, 363-9.

Aoyama, Y. and S. Ratick (2007) Trust, transactions, and information technologies in the US logistics industry. Economic Geography 83.2, 159-80.

Backes, N. (1997) Reading the shopping mall. Journal of Popular Culture 31.3, 1-17.

Bodzin, S. (2003) New life for old malls. Journal of Housing \& Community Development 60.3, 51-5.

Bonacich, E. (2005) Labor and the global logistics revolution, In R. Appelbaum and W. Robinson (eds.), Critical globalization studies, Routledge, New York.

Brennan, D. and L. Kundsten (2000) Impacts of large discount stores on small US towns: reasons for shopping and retailer strategies. International Journal of Retail and Distribution Management 28.4/5, 155-61.

Brill, M. (2001) The problems of mistaking community life for public life. Places 14.2, 4-55.

Burt, S. and L. Sparks (2001) The implications of Walmart's takeover of ASDA. Environment and Planning A 33.8, 1463-89.

Bustillo, M. and A. Zimmerman (2008) Walmart flourishes as economy turns sour. Wall Street Journal 14 November, A1, A11.

Chauncey, G. (1996) Privacy could only be had in public: gay uses of the streets. In J. Sanders (ed.), Stud: architectures of masculinity, Princeton Architectural Press, New York.
City of Toronto (2000) Toronto at the crossroads: shaping our future (executive summary) [WWW document]. URL http:// www.toronto.ca/torontoplan/crossroads_ change.htm (accessed 11 July 2008).

City of Toronto (2001) Scarborough centre toward a new direction [WWW document]. URL http://www.toronto.ca/torontoplan/ scarb_brochure0501.htm (accessed 24 October 2008).

City of Toronto (2002) Toronto official plan. Unpublished draft.

City of Toronto (2003) New official plan Avenues study implementation study report (Phase 3) Kingston Road between the Guildwood GO Station and Highland Creek (Ward 43-Scarborough East) [WWW document]. URL http://www. toronto.ca/legdocs/2003/agendas/council/ cc030624/sc5rpt/c1022.pdf (accessed 21 October 2007).

City of Toronto (2009) Priority neighbourhood area data, social policy analysis and research [WWW document]. URL http://www.toronto.ca/demographics/ pdf/priority2006/priority_investment_ neighbourhoods.pdf (accessed 23 March 2010).

Cohen, L. (2000) From town center to shopping center. In J. Scanlon (ed.), The gender \& consumer culture reader, New York University Press, New York.

Cowen, D. (2005) Suburban citizenship? The rise of targeting and the eclipse of social rights in Toronto. Social \& Cultural Geography, 6.3, 335-56.

Davidson, S. and A. Rummel (2000) Retail changes and Walmart's entry into Maine. International Journal of Retail and Distribution Management 28.4/5, 162-9.

Davis, M. (1990) City of quartz: excavating the future in Los Angeles. Verso, London.

Davis, M. (1997) Ozzie and Harriet in hell. Harvard Design Magazine 1, 1-4.

Dawson, J. (2000) Retailing at century end: some challenges for management and research. The International Review of Retail, Distribution and Consumer Research 10.2, 119-48.

Dawson, J., R. Larke and M. Mukoyama (2006) Strategic issues in international retailing. Routledge, New York.

Dickson, E. (2007) Bands: Scarborough A/V. Wavelength Toronto, 8 April 
[WWW document]. URL http://www. wavelengthtoronto.com/wavelog/2007/04/ scarborough-av (accessed 5 December 2007).

Duncan, H., S. Travis and W. McAuley (1995) An emergent theoretical model for interventions encouraging physical activity (mall walking) among older adults. Journal of Applied Gerontology 14.1, 64-77.

East Scarborough Storefront (ESS) (n.d.) Who we are [WWW document]. URL http://www.thestorefront.org/ESS\%20 Frame.htm (accessed 10 October 2007).

East Scarborough Storefront (ESS) (2004) Community speak — 15 June: 'Future changes to the West Hill area'. Unpublished report.

East Scarborough Storefront (ESS) (2005) Community speak -1 June: 'Stand up for the storefront'. Unpublished report.

Fishman, C. (2006) The Walmart effect. The Penguin Press, New York.

Gray, J. (2005) Even Walmart's leaving. The Globe and Mail 21 May, M1, M4.

Hackworth, J. (2001) Inner-city real-estate investment, gentrification and economic restructuring in New York City. Environment and Planning A 33.5, 863-80.

Hammett, J. and K. Hammett (2007) The suburbanization of New York: is the world's greatest city becoming just another town? Princeton Architectural Press, New York.

Hannigan, J. (1998) Fantasy city: pleasure and profit in postmodern metropolis. Routledge, London.

Hannigan, J. (2005) The new urban political economy. In H. Hiller (2005) (ed.), Urban Canada: sociological perspectives, Oxford University Press, Don Mills, ON.

Haraway, D. (1991) Simians, cyborgs, and women: the reinvention of nature. Routledge, New York.

Harris, R. (2004) Creeping conformity: how Canada became suburban, 1900-1960. University of Toronto Press, Toronto.

Harvey, D. (1990) The condition of postmodernity: an enquiry into the origins of cultural change. Blackwell Publishers, Oxford.

Hernandez, T. (2003) The impact of big box internationalization on a national market: a case study of Home Depot Inc. in Canada. International Review of Retail and Consumer Research 13.1, 77-98.
Hernandez, T. and J. Simmons (2006)

Evolving retail landscapes: power retail in Canada. Canadian Geographer 50.4, 465-86.

hooks, b. (1990) Yearning: race, gender, and cultural politics. Between the Lines, Toronto.

Hulchanski, D. (2007) The three cities within Toronto: income polarization among Toronto's neighbourhoods, 1970-2000. Centre for Urban and Community Studies, University of Toronto.

Hume, J. (2006) Don Mills Centre redevelopment stirs conflict. Spacing Magazine 26 October [WWW document]. URL http://spacing.ca/votes/2006/10/26/ don-mills-centre-redevelopment-stirsconflict/ (accessed 25 November 2008).

Javorcik, B., W. Keller and J. Tybout (2008) Openess and industrial response in a Walmart world: a case study of Mexican soaps, detergents and surfactant producers. The World Economy 31.12, 1558-80.

Jones, K. and M. Doucet (2001) The big box, the flagship, and beyond: impacts and trends in the Greater Toronto Area. Canadian Geographer 45.4, 494-512.

Keil, R. and D. Young (2008) Transportation: the bottleneck of regional competitiveness in Toronto. Environment and Planning C: Government and Policy 26.4, 728-51.

Knights, D. and A. Sturdy (1997) Marketing the soul: from the ideology of consumption to consumer subjectivity. In D. Knights and T. Tinker (eds.), Financial institutions and social transformations, $\mathrm{St}$ Martins Press, New York.

Kunstler, J. (1993) The geography of nowhere: the rise and decline of America's man-made landscape. Simon \& Schuster, New York.

Lefebvre, H. (1991) The production of space. Blackwell, Oxford.

Lewis, G. (1990) Community through exclusion and illusion. Journal of Popular Culture 24.2, 121-36.

Lewis, R.D. (ed.) (2004) The manufacturing suburb: building work and home on the metropolitan fringe. Temple University Press, Philadelphia.

Lorch, B. (2005) Auto dependent induced shopping: exploring the relationship between power centre morphology and consumer spatial behaviour. Canadian Journal of Urban Research 14.2, 36483. 
Lowes, M. (2002) Indy dreams and urban nightmares: speed merchants, spectacle, and the struggle over public space in the world-class city. University of Toronto Press, Toronto.

Lucy, W. and D. Phillips (2000) Suburban decline: the next urban crisis. Issues in Science and Technology 17.1 [WWW document]. URL http://www.issues.org/ 17.1/lucy.htm (accessed 21 October 2008).

Manzo, J. (2002) Community organizing: community as a discursive resource in a youth social services agency. Journal of Mundane Behavior 27.2, 97-110.

Maryland Department of Planning (2001) Managing Maryland's growth: models and guidelines. 'Big-Box' retail development. Maryland Department of Planning, Baltimore.

McKay, D. (2007) Redeveloping greyfields in the Greater Toronto Area. Master's paper, Department of Planning, University of Toronto.

Mckenna, B. and S. Wingrove (2008) GM considers bankruptcy as bailout talks collapse. Globe and Mail 12 December, A1.

Miller, P. and N. Rose (1997) Mobilizing the consumer: assembling the subject of consumption. Theory, Culture and Society 14.1, 1-36.

Mitchell, D. (1995) The end of public space? People's park, definitions of the public, and democracy. Annals of the Association of American Geographers 85.1, 108-33.

Morris, M. (1999) Things to do with shopping centres. In S. During (ed.), The cultural studies reader, Routledge, London and New York.

O'Graff, T. (1998) The locations of Walmart and Kmart supercentres: contrasting corporate strategies. Professional Geographer 50.1, 46-57.

Ortega, B. (1998) In Sam we trust: the untold story of Sam Walton and how Walmart is devouring America. Random House, New York.

Orum, A. and C. Xianming (2003) The world of cities: places in comparative historical perspective. Blackwell, Oxford.

Parker, S. (2004) Urban theory and the urban experience. Routledge, London.

Peterson, M. and J. McGee (2000) Survivors of 'W-Day': an assessment of the impact of Walmart's invasion of small town retailing communities. International
Journal of Retailing and Distribution Management 28.4/5, 170-80.

Philp, M. (1996) Costly motels serve as a housing shelter: expense double that of welfare rates. Globe and Mail 21 February, A8.

Planning Action (2006) Public space in the suburbs? [WWW document]. URL http:// www.planningaction.org/ (accessed 25 November 2008).

Pollock, J. (1992) Malls struggle to keep customers. Marketing Magazine 9 November, 18-19.

Prytherch, D. (2007) Urban geography with scale: rethinking scale via Walmart's geography of big things. Urban Geography 28.5, 456-82.

Short, J., B. Hanlon and T. Vicino (2007) The decline of inner suburbs: the new suburban gothic in the United States. Geography Compass 1.3, 641-56.

Smith, N., P. Caris and W. Wyly (2001) 'The Camden syndrome' and the menace of suburban decline: residential disinvestment and its discontents in Camden County, New Jersey. Urban Affairs Review 36.4, 497-531.

Smith, N. (2002) New globalism, new urbanism: gentrification as global urban strategy. Antipode 34.3, 427-50.

Spector, R. (2005) Category killers: the retail revolution and its impact on consumer culture. Harvard Business School Press, Boston.

Staeheli, L. and D. Mitchell (2006) USA's destiny? Regulating space and creating community in American shopping malls. Urban Studies 43.5, 977-92.

Turner, M. (2003) Kmart's ten deadly sins: how incompetence tainted an American icon. John Wiley \& Sons Inc, New Jersey.

United Way of Greater Toronto (2002) A decade of decline: poverty and income inequality in the city of Toronto in the 1990s. United Way of Greater Toronto, Toronto.

Valentine, G. (1993) (Hetero)sexing space: lesbian perceptions and experiences of everyday spaces. Environment and Planning D 11.4, 395-414.

Vias, A. (2004) Bigger stores, more stores, or no stores: retail restructuring in rural America. Journal of Rural Studies 20.3, 303-18.

Walks, R.A. (2001) The social ecology of the post-Fordist/global city? Economic 
restructuring and social-spatial polarisation in the Toronto urban region. Urban Studies 38.3, 407-47.

West-hill Community association (n.d.) Homepage [WWW document]. URL http:// west-hill.com/commercial.html (accessed 25 November 2008).

White, J. and K. Gray (1996) Shopping centres and other retail properties: investment, development, financing and management. Wiley, Toronto.
Wood, S. (2002) Organizational restructuring, knowledge and spatial scale: The case of the US department store industry. Tijdschrift voor Economische en Sociale Geograffe 93.1, 8-33.

Wrigley, N. and M. Lowe (2002) Reading retail: a geographical perspective on retailing and consumption spaces. Hodder Arnold Publication, London and New York.

\section{Résumé}

Toute une catégorie de l'espace urbain (rarement reconnue comme telle) est en voie de disparition en Amérique du Nord. Tandis que la logistique du commerce de détail se mondialise et que les méga-zones commerciales remplacent les centres commerciaux de l'après-guerre, une forme particulière d'infrastructure sociale s'éteint. Les sites abandonnés des Dead malls marquent désormais les paysages (sub)urbains nordaméricains, suscitant des actions de défense locales. Pourtant, malgré l'inquiétude des habitants pour ces espaces commerciaux, les critiques en sciences urbaines ont généralement marginalisé le phénomène. En grande partie, le contraste entre le tollé des populations et le silence des intellectuels tient au concept d'espace 'public', plus précisément au décalage entre la propriété officielle et la pratique spatiale quotidienne. Cette dernière dépasse souvent les idées des concepteurs et gérants, le lieu devenant un espace communautaire. C'est notamment le cas dans les quartiers périphériques du centre qui dépérissent et où des communautés pauvres et racialisées dépendent davantage des malls, tant en matière de reproduction sociale que de détente et de consommation. L'article décrit la révolution logistique à l'origine du phénomène des Dead malls, ainsi que les actions de défense créatives qui visent à préserver l'espace commercial en tant qu'espace communautaire. À partir du cas de Morningside Mall situé dans une banlieue ancienne de Toronto, l'étude s'intéresse aux revendications informelles de cet espace manifestées à travers la pratique spatiale quotidienne, et aux revendications explicites d'espace communautaire qui naissent lorsque cet espace est menacé. Il est montré que de nombreux centres commerciaux sont en effet devenus des espaces communautaires, et que les actions menées pour éviter leur disparition peuvent se comprendre comme une forme de pratique antimondialiste, même si elles ne s'expriment pas en ces termes. 